\title{
An Amino Acid Sequence in the Active Site of Lipoamide Dehydrogenase from Pig Heart
}

\author{
By JOSEPH P. BROWN and RICHARD N. PERHAM \\ Department of Biochemistry, University of Cambridge, Tennis Court Road, \\ Cambridge CB2 $1 Q W, U . K$.
}

(Received 16 August 1973)

\begin{abstract}
1. The two cysteine residues forming the disulphide bridge that comprises part of the active site of lipoamide dehydrogenase from pig heart were specifically labelled with iodo $\left[2-{ }^{14} \mathrm{C}\right]$ acetic acid. 2. A tryptic peptide containing these carboxymethylcysteine residues was isolated from digests of reduced and $S$-carboxymethylated lipoamide dehydrogenase and its amino acid sequence of 23 residues was determined. 3 . The sequence is highly homologous with a similar sequence containing the active-site disulphide bridge of lipoamide dehydrogenase derived from the 2-oxoglutarate dehydrogenase complex of Escherichia coli (Crookes strain) and it is probable that, as in the bacterial enzyme, the disulphide bridge forms an intrachain loop containing six residues. The results indicate that the bacterial and mammalian proteins have a common genetic origin. 4. Amino acid sequences containing six other unique carboxymethylcysteine residues were also partly determined. 5. The analysis of the primary structure thus far is consistent with the view that the enzyme (mol.wt. approx. 110000) is composed of two identical polypeptide chains.
\end{abstract}

Lipoamide dehydrogenase (NADH-lipoamide oxidoreductase, EC 1.6.4.3) is a component of the pyruvate dehydrogenase and 2-oxoglutarate dehydrogenase multienzyme complexes [for a review, see Reed \& Oliver (1968)]. It has been isolated from a number of sources, among them Escherichia coli (Koike et al., 1960; Mukherjee et al., 1965; Williams et al., 1967) and pig heart muscle (Massey, 1966; Sakurai et al., 1970). The enzyme is a flavoprotein and uses, as part of its reaction mechanism, the alternate oxidation and reduction of a disulphide bridge in its active site (Massey et al., 1960; Massey \& Veeger, 1961). This disulphide bridge provides a convenient starting point for chemical studies of the active site, and in a previous paper (Brown \& Perham, 1972) we have described a simple technique for specifically labelling its constituent cysteine residues and reported an amino acid sequence of 17 residues, which includes the disulphide bridge, for the enzyme from the 2-oxoglutarate dehydrogenase complex of $E$. coli (Crookes strain). This sequence is in complete agreement with a sequence of 11 residues surrounding the active-site disulphide bridge of the enzyme from E. coli B (Burleigh \& Williams, 1972).

These studies of primary structure have provided conclusive evidence for the existence of a unique disulphide bridge in each of the two polypeptide chains (mol.wt. approx. 55000) that comprise the bacterial enzyme and are consistent with the view that the polypeptide chains are probably identical. The enzyme from pig heart muscle is also a dimer (mol.wt. approx. 110000) and it is important to know whether the mammalian and bacterial enzymes are evolutionarily related. In the present paper we describe the determination of an amino acid sequence of 23 residues that includes the active-site disulphide bridge of the pig heart enzyme and give partial sequences for six unique cysteine residues. The total number of residues accounted for in this way is 71 , of which 60 are in established sequences. From a comparison with the corresponding sequences for the enzyme from E. coli (Brown \& Perham, 1972; J. P. Brown \& R. N. Perham, unpublished work), we infer that the bacterial and mammalian enzymes are closely homologous in structure and conclude that they share a common ancestral form.

\section{Materials and Methods}

\section{Reagents and enzymes}

Lipoamide dehydrogenase from pig heart was obtained from C. F. Boehringer und Soehne G.m.b.H., Mannheim, Germany. Iodoacetic acid was purchased from BDH Chemicals Ltd., Poole, Dorset, U.K., and $N$-ethylmaleimide from Sigma Chemical Co., St. Louis, Mo., U.S.A. 2-Mercaptoethanol was obtained from Eastman-Kodak Ltd., Kirkby, Lancs., U.K. Iodo $\left[2-{ }^{14} \mathrm{C}\right]$ acetic acid was purchased from The Radiochemical Centre, Amersham, Bucks, U.K., and diluted with carrier iodoacetic acid to a specific radioactivity of $2.0 \mathrm{mCi} /$ mmol before use. Trypsin and chymotrypsin 
(twice recrystallized) were purchased from Worthington Biochemical Corp., Freehold, N.J., U.S.A., and thermolysin $(3 \times$ recrystallized) was from Calbiochem Ltd., London W.1, U.K. $\beta$-Trypsin was kindly provided by Dr. John Kay. Carboxypeptidase C was obtained from Roehm G.m.b.H., Darmstadt, Germany. The enzyme (5000munits) was dissolved in $0.06 \mathrm{M}$-sodium citrate buffer, $\mathrm{pH} 5.3$, before use. All other chemicals were of analytical grade.

\section{Complete alkylation of enzyme thiol groups}

Proteins were $S$-carboxymethylated in $0.1 \mathrm{M}$-Tris$\mathrm{HCl}$ buffer, $\mathrm{pH} 8.0$, in the presence of $6 \mathrm{M}$-guanidine hydrochloride and $2 \mathrm{~mm}$-dithiothreitol as described by Gibbons \& Perham (1970).

\section{Polyacrylamide-gel electrophoresis}

Samples of $S$-carboxymethylated protein were run in $7.5 \%(\mathrm{w} / \mathrm{v})$ polyacrylamide gels containing $0.1 \%$ sodium dodecyl sulphate (Shapiro \& Maizel, 1969; Weber \& Osborn, 1969). The markers used for the estimation of molecular weight were bovine serum albumin (mol.wt. 68000), pig muscle glyceraldehyde 3-phosphate dehydrogenase (subunit mol.wt. 36000) and hen's-egg-white lysozyme (mol.wt. 14300). A linear plot for $\log$ (mol.wt.) against electrophoretic mobility was obtained.

\section{Radioactivity measurements}

Samples were added to $3 \mathrm{ml}$ of toluene-Triton (2:1, v/v) containing 2,5-diphenyloxazole $(0.5 \%$, $\mathrm{w} / \mathrm{v})$ and counted for radioactivity in a NuclearChicago Unilux IIA scintillation counter.

\section{Amino acid analysis}

Samples of peptides and protein were hydrolysed for $24 \mathrm{~h}$ at $105^{\circ} \mathrm{C}$ with $6 \mathrm{M}-\mathrm{HCl}$ containing $0.1 \%(\mathrm{v} / \mathrm{v})$ 2-mercaptoethanol in sealed evacuated tubes. The amino acids were analysed either on a Beckman 120C automatic amino acid analyser (peptides and proteins) or by a highly sensitive double-isotope technique using ${ }^{3} \mathrm{H}$-labelled dansyl chloride (peptides only) (Brown \& Perham, 1973). The values for serine and threonine were corrected, by 6 and $3 \%$ respectively, for destruction during $24 \mathrm{~h}$ of hydrolysis (Perham, 1967).

\section{Separation and characterization of peptides}

Paper electrophoresis, chromatography and dansyl-Edman degradation of peptides were carried out as described previously (Gibbons et al., 1970). Peptides were also purified by gel filtration on Sephadex G-50 (superfine grade), Sephadex G-25 (superfine grade) (Pharmacia Fine Chemicals AB, Uppsala, Sweden) or Bio-Gel P2 (100-200 mesh)
(Bio-Rad Laboratories, Richmond, Calif., U.S.A.) and by chromatography on DEAE-cellulose, grade DE-52 (Whatman; W. and R. Balston Ltd., Maidstone, Kent, U.K.). Special columns $(150 \mathrm{~cm} \times 0.65 \mathrm{~cm}$ or $65 \mathrm{~cm} \times 0.65 \mathrm{~cm})$ and fittings were purchased from Biolab Ltd., Cambridge CB2 1DB, U.K. Peptide 'maps' and radioautographs were prepared by the method of Harris \& Perham (1965) and amide assignments were made from the electrophoretic mobility $(m)$ of the peptide at pH6.5 (Offord, 1966), defining the mobility of aspartic acid as -1.00 .

\section{Digestion with proteolytic enzymes}

Tryptic and chymotryptic digestion were carried out as previously described (Gibbons et al., 1970). For a mixed tryptic-chymotryptic digestion, the protein was digested initially with trypsin $(1 \%, w / w)$ for $4 \mathrm{~h}$ at $37^{\circ} \mathrm{C}$ and chymotrypsin $(1 \%, \mathrm{w} / \mathrm{w})$ was then added and the digestion continued for a further 4h. Peptides were digested with thermolysin (approx. $1 \mu \mathrm{g} / \mathrm{nmol}$ of peptide) at $50^{\circ} \mathrm{C}$ for $5 \mathrm{~h}$ in $0.5 \%(\mathrm{w} / \mathrm{v}) \mathrm{NH}_{4} \mathrm{HCO}_{3}, \mathrm{pH} 8.0$.

Peptides were digested with carboxypeptidase C (1 munit/nmol of peptide) in $0.01 \mathrm{M}$-sodium citrate buffer, pH5.3, at $37^{\circ} \mathrm{C}$. Amino acids released were determined quantitatively by the double-isotope method of Brown \& Perham (1973).

\section{Results \\ General characterization of lipoamide dehydrogenase}

Pig heart lipoamide dehydrogenase was reduced with dithiothreitol and $S$-carboxymethylated with iodo[2-14 C]acetic acid. The protein gave a single band, apparent mol.wt. approx. 55000, on electrophoresis in sodium dodecyl sulphate-polyacrylamide gels. Amino acid analysis based on a subunit mol.wt. of 55000 indicated a total of $10.6 S$-carboxymethylcysteine residues/subunit, which is in moderately good agreement with the value of 10 half-cystine residues given elsewhere (Massey et al., 1962; Williams \& Arscott, 1972).

Tryptic peptide 'maps' of the $S$-carboxymethylated protein were unpromising in that a radioautograph showed two or three major radioactive peptides and a considerable amount of radioactivity at the origin. However, a tryptic-chymotryptic 'map' showed eight major radioactive peptides and no radioactivity at the origin.

Samples of the enzyme were also examined by using electrophoresis in sodium dodecyl sulphate-polyacrylamide gels without prior reduction and $S$-carboxymethylation of the protein. The enzyme was dissolved in $0.05 \mathrm{M}$-sodium phosphate buffer, $\mathrm{pH} 7.0$, containing $10 \%(\mathrm{v} / \mathrm{v})$ glycerol and $0.5 \%$ 
sodium dodecyl sulphate and the solution was heated at $100^{\circ} \mathrm{C}$ for $1 \mathrm{~min}$ before being cooled and applied to the gel. The protein gave a single band with an apparent mol.wt. of approx. 55000 . Since this method of preparation for gel electrophoresis omitted the conventional reduction of the protein with 2mercaptoethanol (Shapiro \& Maizel, 1969; Weber \& Osborn, 1969), we conclude that any disulphide bridges in the native enzyme must be intrachain rather than interchain. This view is further supported by the fact that lipoamide dehydrogenase, in which all free thiol groups had been alkylated with $\mathrm{N}$ ethylmaleimide at pH7.0 in the phosphate-glycerolsodium dodecyl sulphate buffer without prior reduction, also gave a single band of apparent mol.wt. 55000 when subjected to electrophoresis. Unless a rapid and very specific rearrangement of interchain to intrachain disulphide bridges is taking place in all these experiments, these results are best explained by the disulphide bridges being intrachain.

\section{Identification of the active-site peptide}

Native pig-heart lipoamide dehydrogenase was $S$-carboxymethylated with unlabelled iodoacetic acid without prior reduction by dithiothreitol, crystalline guanidine hydrochloride (final concentration $6 \mathrm{M}$ ) being added gradually to the protein solution after the iodoacetic acid. After extensive dialysis against glass-distilled water, the protein was recovered by freeze-drying and then reduced and $S$-carboxymethylated with iodo $\left[2-{ }^{14} \mathrm{C}\right]$ acetic acid under the usual conditions of reduction and denaturation (see Brown \& Perham, 1972). A radioautograph of a tryptic peptide 'map' of this material showed one major radioactive peptide $(m=-0.41)$, designated $\mathrm{T} 1$, and traces of radioactivity at the origin. A tryptic-chymotryptic peptide map showed one major radioactive peptide, DTC $2 n 1$ $(m=0.00)$, and three minor radioactive peptides. The minor peptides were clearly different from any of the tryptic-chymotryptic peptides whose sequences were determined in a separate series of experiments described below (see Fig. 1).

In a similar experiment, the thiol groups in the denatured enzyme were blocked with $10 \mathrm{~mm}-N$-ethylmaleimide in $0.1 \mathrm{M}$-potassium phosphate buffer, pH 7.0, instead of with unlabelled iodoacetic acid at pH 8.0. Peptide 'maps' of this protein after reduction and $S$-carboxymethylation with iodo[ $\left[2-{ }^{14} \mathrm{C}\right]-$ acetic acid showed essentially the same result as the previous experiment, indicating that the minor radioactive peptides were not due to disulphide interchange that might have taken place in guanidine hydrochloride at the higher $\mathrm{pH}$. They probably represent partial overlapping enzymic cleavages in the primary structure surrounding a labelled cysteine residue (see below).

\section{Amino acid sequences around the half-cysteine residues} of the enzyme

To derive the maximum information from a limited amount of protein, we decided to attempt the determination of the amino acid sequence around all the half-cysteine residues of the protein: the cysteine residues involved in the active-site disulphide bridge were known to be in peptide $\mathrm{T} 1$ and could be identified on that basis. Lipoamide dehydrogenase $(50 \mathrm{mg})$ was reduced and $S$-carboxymethylated with iodo $\left[2-{ }^{14} \mathrm{C}\right]$ acetic acid in the presence of $6 \mathrm{M}$ guanidine hydrochloride, digested first with trypsin and then with chymotrypsin, after which the peptides were fractionated on a column $(120 \mathrm{~cm} \times 2 \mathrm{~cm})$ of Sephadex G-25 (superfine grade) in $0.5 \%$ $\mathrm{NH}_{4} \mathrm{HCO}_{3}, \mathrm{pH}$ 8.0. Radioactivity in the column effluent was determined by scintillation counting. By submitting a sample from each fraction to paper electrophoresis at $\mathrm{pH} 6.5$, the fractions containing radioactive peptides were pooled optimally. The radioactive peptides were purified by successive paper electrophoresis and chromatography. Amino acid compositions and a summary of the peptide purifications are shown in Table 1.

The peptides were characterized by means of the dansyl-Edman degradation and amide assignments were made from the electrophoretic mobilities of the peptides. On the basis of its mobility on electrophoresis at pH6.5 and on paper chromatography, peptide DTC2n1 was identified with the major tryptic-chymotryptic peptide labelled in the previous experiment. The sequences of the trypticchymotryptic peptides are shown in Fig. 1.

\section{Purification of a tryptic peptide (DT2a) containing $S$-carboxymethylcysteine residues derived from the active-site disulphide bridge}

Lipoamide dehydrogenase $(50 \mathrm{mg})$ was reduced and $S$-carboxymethylated with iodo $\left[2-{ }^{14} \mathrm{C}\right]$ acetic acid in the presence of $6 \mathrm{M}$-guanidine hydrochloride, then digested with trypsin, and the peptides were fractionated on a column $(120 \mathrm{~cm} \times 2 \mathrm{~cm})$ of Sephadex G-50 (superfine grade) in $0.5 \% \mathrm{NH}_{4} \mathrm{HCO}_{3}$. Radioactivity in the column effluent was determined by scintillation counting and a sample of each fraction was examined by paper electrophoresis at $\mathrm{pH}$ 6.5. The fractions were pooled as shown in Fig. 2 and freezedried. Peak DT2 contained only one radioactive peptide and its mobility $(m=-0.41)$ suggested that it was the same as the tryptic peptide T1 $(m=-0.41)$, which was observed in the earlier experiment designed to label the active-site disulphide bridge. No other tryptic peptides with the appropriate mobility were found in the other peaks. Two samples of peak DT2 were digested with different amounts of chymotrypsin, as were two similar samples of peptide T1 that had been eluted from a peptide 'map'. Radioautographs 


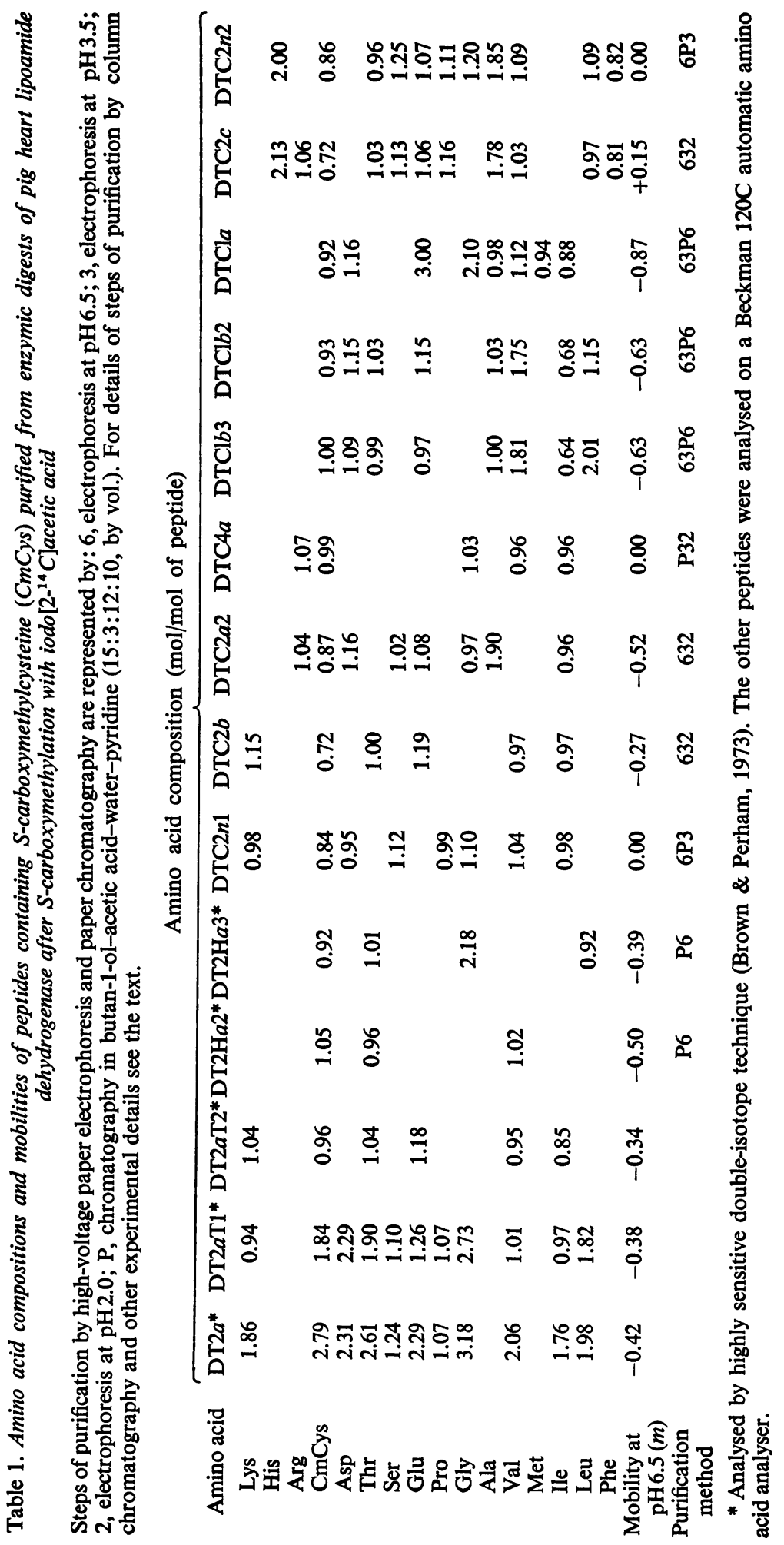




\begin{tabular}{|c|c|}
\hline Peptide & Amino acid sequence \\
\hline DTCla & 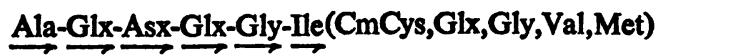 \\
\hline DTClb2 & $\stackrel{\mathrm{Ala}}{\longrightarrow}(\mathrm{Glu}, \mathrm{Val}, \mathrm{Ile}, \mathrm{Thr}, \mathrm{CmCys}, \mathrm{Asp}, \mathrm{Val}, \mathrm{Leu})$ \\
\hline DTC1b3 & $\stackrel{\text { Ala-Glu-Val-Ile-Thr-CmCys-Asp-Val-Leu-Leu }}{\longrightarrow}$ \\
\hline DTC2a2 & Gly-Ala-Ser-CmCys-Glu-Asp-Ile-Ala-Arg \\
\hline DTC2b & Thr-Val-CmCys-Ile-Glu-Lys \\
\hline DTC2n1 & Asn-Val-Gly-CmCys-Ile-Pro-Ser-Lys \\
\hline DTC2c & 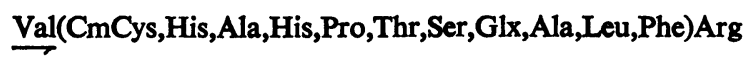 \\
\hline DTC2n2 & Val-CmCys-His-Ala-His-Pro(Thr,Ser,Glx,Ala,Leu,Phe) \\
\hline DTC4a & Val-CmCys-Ile-Gly-Arg \\
\hline
\end{tabular}

Fig. 1. Partial amino acid sequences of peptides containing S-carboxymethylcysteine purified from a tryptic-chymotryptic digest of pig heart lipoamide dehydrogenase after S-carboxymethylation with iodo $\left[2-{ }^{14} \mathrm{C}\right]$ acetic acid

represents a residue placed by the dansyl-Edman degradation. The arginine residue at the $C$-terminus of peptide DTC 2 is placed by comparison with peptide DTC $2 n 2$.

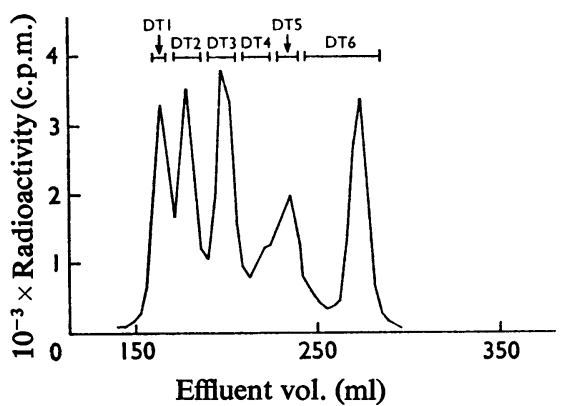

Fig. 2. Separation of radioactive peptides from a tryptic digest of pig heart lipoamide dehydrogenase after $S$-carboxymethylation with iodo[2-14 C]acetic acid

Gel filtration was carried out on a column $(120 \mathrm{~cm} \times 2 \mathrm{~cm})$ of Sephadex G-50 (superfine grade) in $0.5 \% \mathrm{NH}_{4} \mathrm{HCO}_{3}$, pH 8. Peak DT6 contained no radioactive peptides and was derived from excess of reagent that had not been removed completely by dialysis.

of peptide 'maps' of these digests were very similar; they all showed a neutral (at $\mathrm{pH} 6.5$ ) radioactive peptide that had the same electrophoretic and chromatographic mobilities as the tryptic-chymotryptic peptide DTC2n1, which had also been observed in the active-site labelling experiment. The maps additionally showed one or two anionic radioactive peptides of similar electrophoretic and chromatographic mobilities, comparable with those observed in the tryptic-chymotryptic digest of enzyme specifically labelled in the active site (see below). These peptides, as before, were rather variable in yield, depending on the amount of chymotrypsin used, and attempts to establish their identity were unsuccessful because of their low yield.

The single radioactive peptide in peak DT2 was purified by chromatography on a column $(60 \mathrm{~cm} \times$ $0.65 \mathrm{~cm}$ ) of DEAE-cellulose (DE-52) equilibrated with $0.5 \% \mathrm{NH}_{4} \mathrm{HCO}_{3}$ and eluted by a linear gradient $(0.5-2.0 \%, w / v)$ of $\mathrm{NH}_{4} \mathrm{HCO}_{3}$. The effluent was monitored by measurement of radioactivity and $E_{230}$ in the fractions. A single peak of radioactivity was eluted when the gradient had reached about $1.0 \%$ $\mathrm{NH}_{4} \mathrm{HCO}_{3}$. The appropriate fractions were pooled, evaporated to dryness in vacuo and re-chromatographed on the same column under equilibrium conditions in $1.0 \% \mathrm{NH}_{4} \mathrm{HCO}_{3}$. A single symmetrical peak of radioactivity coincident with the $E_{230}$ peak was eluted and the appropriate fractions were pooled and evaporated to dryness in vacuo. The pure peptide was designated DT2a.

\section{Characterization of peptide DT2a}

The amino acid composition of peptide DT2a is shown in Table 1. The peptide has three residues 

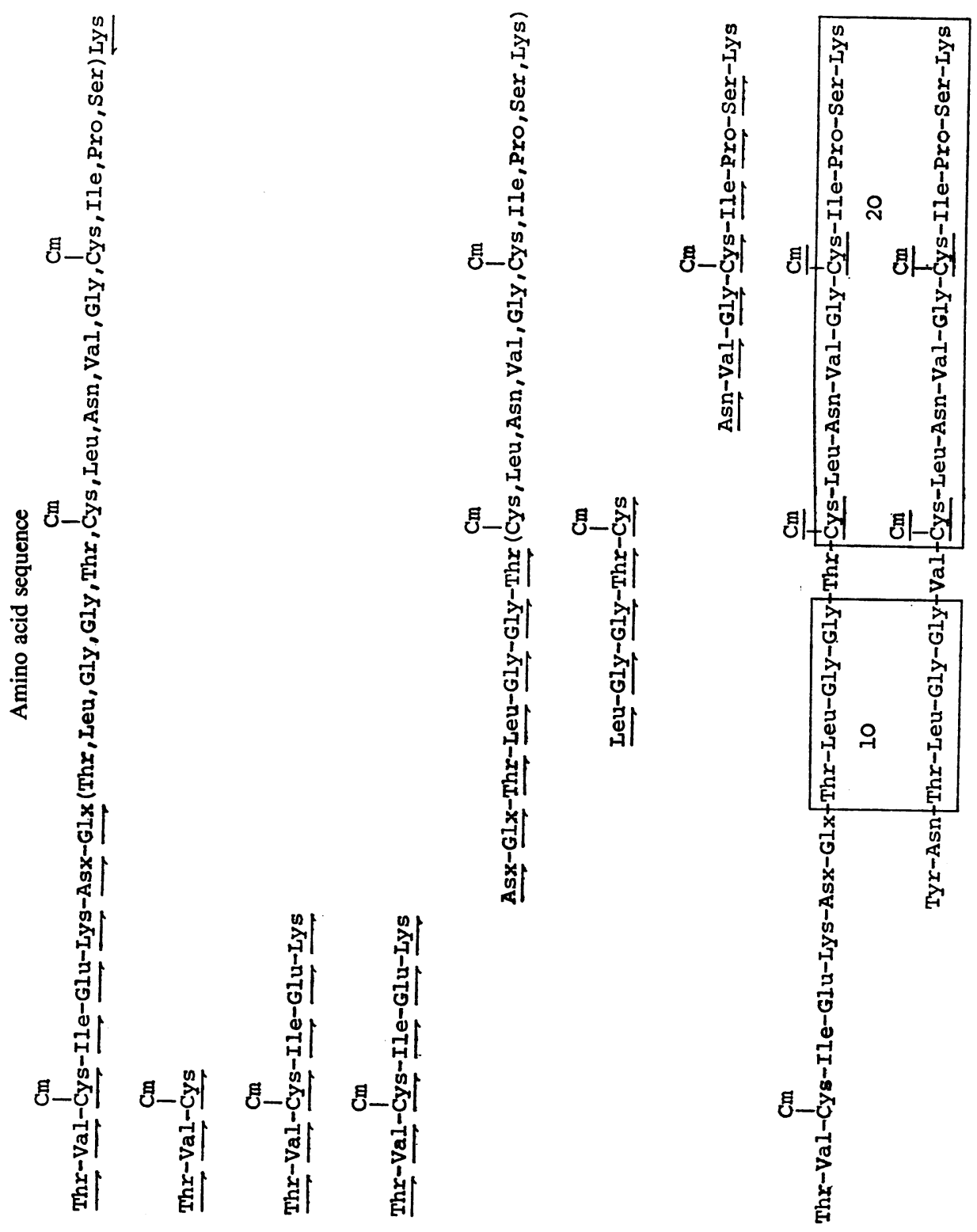

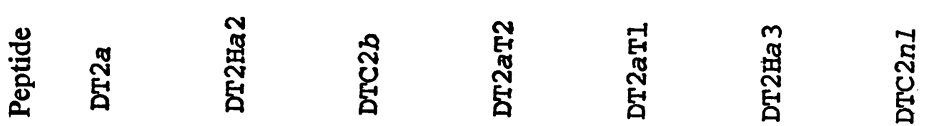

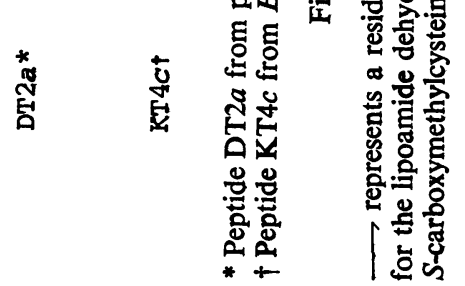


of $S$-carboxymethylcysteine (CmCys) and also two residues of lysine. The sequence of the first eight residues was determined by dansyl-Edman degradation as shown in Fig. 3. The first six residues, Thr-Val-CmCys-Ile-Glu-Lys, are the same as in the tryptic-chymotryptic peptide DTC2 $b$, the sequence of which had already been determined (Fig. 1).

In view of the lysine residue at position 6, which is evidently involved in a peptide bond that is only very slowly hydrolysed by trypsin, about $20 \mathrm{nmol}$ of peptide DT2 $a$ was digested with $\beta$-trypsin $(1 \mu \mathrm{g} / \mathrm{nmol})$ in $0.5 \% \mathrm{NH}_{4} \mathrm{HCO}_{3}$ at $37^{\circ} \mathrm{C}$ for $5 \mathrm{~h}$. The digest was fractionated on a column $(140 \mathrm{~cm} \times 0.65 \mathrm{~cm})$ of Sephadex G-50 (superfine grade) in $0.5 \% \mathrm{NH}_{4} \mathrm{HCO}_{3}$, and the radioactivity in the effluent monitored by scintillation counting. The two radioactive peaks, peptides DT2 $a \mathrm{~T} 1$ and DT2aT2, were pooled separately and evaporated to dryness. Their amino acid compositions are shown in Table 1 and their sequences, determined by dansyl-Edman degradation, are given in Fig. 3. The $\beta$-trypsin appears to have cleaved specifically between Lys- 6 and Asx-7.

In a further experiment, peak DT2 was digested with thermolysin and peptides DT2 $\mathrm{Ha}_{2}$ and DT2Ha3 were purified by chromatography on a column $(120 \mathrm{~cm} \times 2 \mathrm{~cm})$ of Sephadex G-25 (superfine grade) in $0.5 \% \mathrm{NH}_{4} \mathrm{HCO}_{3}$ and by paper electrophoresis. Their sequences are also included in Fig. 3.

\section{Discussion}

Earlier studies on pig heart lipoamide dehydrogenase have suggested that there are ten half-cystine residues/polypeptide chain, of which six or seven are free thiol groups and two or four are involved in disulphide bridges (Massey et al., 1962; Williams et al., 1971; Williams \& Arscott, 1972). If we make the reasonable assumption that peptides DTC1b2 and DTC1 $b 3$ are derived from the same sequence and that peptides DTC $2 c$ and DTC $2 n 2$ also share a common sequence, eight unique half-cystine residues have been identified in the present work (peptides DTC1a, DTC1b3, DTC2a2, DTC2 $b$, DTC2n1, DTC2n2, DTC4a and DT2Ha3; Figs. 1 and 3). Good evidence has been obtained that one of these residues (residue 19 in peptide DT2 $a$; Fig. 3 ) is involved in a disulphide bridge in the native enzyme, since it is located in the active-site peptide DTC $2 n 1$. Direct evidence for the identity of its partner is lacking. The only radioactive tryptic peptide observed in the active-site-labelling experiment is peptide $\mathrm{T} 1$ (otherwise peptide DT2a). It therefore seems probable that the partner of residue 19 in peptide DT $2 a$ is either residue 3 or residue 14 . When the tryptic-chymotryptic digest of activesite-labelled enzyme was examined, peptide DTC $2 n 1$ was recognized (implicating residue 19), but the other radioactive peptides could not be positively identified. It was clear, however, that none of the radioactive peptides was peptide DTC2 $b$ (residue 3 of peptide DT2a), since this peptide might have been expected to be observed even in poor yield had it been labelled because it was isolated in good yield from the corresponding digest of the totally $S$-carboxymethylated enzyme (Fig. 1). The evidence therefore indicates that residue 14 of peptide DT2 $a$ is the other half of the active-site disulphide bridge. The action of chymotrypsin on peptide DT $2 a$ might well produce a pattern of overlapping anionic peptides containing residue 14 , in accordance with our observations. Strong support for these conclusions comes from the close homology with the activesite sequence for the enzyme from $E$. coli, as discussed below.

All our evidence suggests that there is only one disulphide bridge/polypeptide chain, although it must be stressed that the presence of a second disulphide bridge cannot be excluded. Similar reservations have been expressed by Williams \& Arscott (1972). However, the present sequence analysis has produced no evidence of heterogeneity in the polypeptide chains, the number of unique half-cystine residues recognized thus far being only slightly fewer than the number of such residues indicated by amino acid analysis (Massey et al., 1962; Williams \& Arscott, 1972). It therefore seems safe to conclude that the two polypeptide chains in the native enzyme are very similar, if not identical (Massey et al., 1962).

Fig. 3 shows a comparison between the amino acid sequence containing the proposed disulphide bridge at the active site of pig heart lipoamide dehydrogenase and the corresponding sequence for the lipoamide dehydrogenase from the 2-oxoglutarate dehydrogenase complex of $E$. coli (Crookes strain) (Brown \& Perham, 1972). The pig heart sequence described here is slightly different from the sequence of 17 residues (positions 7-23) independently determined by Williams \& Arscott (1972). The primary structures of the bacterial and pig heart enzymes are highly homologous in this region and, indeed, the homology is remarkably extensive for two proteins from sources so widely separated phylogenetically. The disulphide bridge in the active site of the bacterial enzyme has been proved to comprise residues 14 and 19 (Brown \& Perham, 1972) and we believe that the sequence homology argues strongly for an identical arrangement in the enzyme from pig heart. Further, we conclude that the proteins are derived by divergent evolution from a common ancestor.

It is interesting that there is a free thiol group close to the active-site disulphide bridge in the pig heart enzyme. No evidence of a comparable thiol group in the enzyme from $E$. coli has yet been

Vol. 137 
obtained and, indeed, if the sequences around the six free cysteine residues of the pig heart enzyme, recorded in Fig. 1, are compared with the sequences around the three free thiol groups in the polypeptide chain of the bacterial enzyme, no further evidence of homology is apparent (Brown \& Perham, 1972; J. P. Brown \& R. N. Perham, unpublished work). However, given the fact that both lipoamide dehydrogenases are dimers of approx. mol.wt. 110000 , that they are highly homologous around the active site disulphide bridge and that the pig heart enzyme will complement with reasonable efficiency the sub-complex of pyruvate decarboxylase and dihydrolipoyl transacetylase from $E$. coli in the pyruvate dehydrogenase reaction in vitro (Guest \& Creaghan, 1973; R. A. Harrison, unpublished work), it is probable that they will have a closely similar three-dimensional structure.

Finally, it should be remarked that the active-site disulphide bridge of pig heart lipoamide dehydrogenase is almost certainly an intrachain bridge containing only four additional amino acids, a situation identical with that previously found for the enzyme from $E$. coli (Burleigh \& Williams, 1972; Brown \& Perham, 1972). Other flavoprotein oxidoreductases that have catalytically essential disulphide bridges include thioredoxin reductase and glutathione reductase (reviewed by Williams et al., 1971). It is significant that for thioredoxin (Hölmgren, 1968) and thioredoxin reductase (Thelander, 1970; Ronchi \& Williams, 1972) the essential disulphide bridge is also intrachain and formed by cysteine residues only two residues apart. The small intrachain disulphide bridge is evidently a feature of such enzymes and is probably a consequence of the need to prevent the constituent cysteine residues from becoming inadvertently separated in space as a result of fluctuation of the protein conformation when the enzyme is in the reduced form (Brown \& Perham, 1972).

We thank Dr. John Kay for helpful discussion and a gift of $\beta$-trypsin. We are grateful to the Medical Research Council for a Scholarship awarded to J. P. B. and to the Science Research Council for financial support (Grant B/SR/9480).

\section{References}

Brown, J. P. \& Perham, R. N. (1972) FEBS Lett. 26, 221-224

Brown, J. P. \& Perham, R. N. (1973) Eur. J. Biochem. 39, 69-73

Burleigh, B. D., Jr. \& Williams, C. H., Jr. (1972) J. Biol. Chem. 247, 2077-2082

Gibbons, I. \& Perham, R. N. (1970) Biochem. J. 116, 843-849

Gibbons, I., Anderson, P. J. \& Perham, R. N. (1970) FEBS Lett. 10, 49-53

Guest, J. R. \& Creaghan, I. T. (1973) J. Gen. Microbiol. 75, 197-210

Harris, J. I. \& Perham, R. N. (1965) J. Mol. Biol. 13, 876-884

Hölmgren, A. (1968) Eur. J. Biochem. 6, 475-484

Koike, M., Shah, P. C. \& Reed, L. J. (1960) J. Biol. Chem. 235, 1939-1943

Massey, V. (1966) Methods Enzymol. 9, 272-278

Massey, V. \& Veeger, C. (1961) Biochim. Biophys. Acta $48,33-47$

Massey, V., Gibson, Q. H. \& Veeger, C. (1960) Biochem.J. 77, 341-351

Massey, V., Hoffman, T. \& Palmer, G. (1962) J. Biol. Chem. 237, 3820-3828

Mukherjee, B. B., Matthews, J., Horney, D. L. \& Reed, L. J. (1965) J. Biol. Chem. 240, PC2268-PC2269

Offord, R. E. (1966) Nature (London) 211, 591-593

Perham, R. N. (1967) Biochem. J. 105, 1203-1207

Reed, L. J. \& Oliver, B. M. (1968) Brookhaven Symp. Biol. 21, 397-412

Ronchi, S. \& Williams, C. H., Jr. (1972) J. Biol. Chem. 247, 2083-2086

Sakurai, Y., Fukoyoshi, Y., Hamada, M., Hayahawa, T. \& Koike, M. (1970) J. Biol. Chem. 245, 4453-4462

Shapiro, A. L. \& Maizel, J. V., Jr. (1969) Anal. Biochem. 29, 505-514

Thelander, L. (1970) J. Biol. Chem. 245, 6026-6029

Weber, K., \& Osborn, M. (1969) J. Biol. Chem. 244, 4406-4412

Williams, C. H., Jr. \& Arscott, L. D. (1972) Z. Naturforsch. B 27, 1078-1080

Williams, C. H., Jr., Zanetti, G., Arscott, L. D. \& McAllister, J. K. (1967) J. Biol. Chem. 242, 5226-5231

Williams, C. H., Jr., Burleigh, B. D., Jr., Ronchi, S., Arscott, L. D. \& Jones, E. T. (1971) in Flavins and Flavoproteins (Kamin, H., ed.), vol. 3, pp. 295-377, University Park Press, Baltimore 